\begin{tabular}{|c|c|c|}
\hline \multirow{2}{*}{$\mathrm{Ver}$} & $\begin{array}{l}\text { International Journal of Current Research in } \\
\text { Biosciences and Plant Biology }\end{array}$ & $=$ \\
\hline & Volume $5 \bullet$ Number 11 (November-2018) • ISSN: 2349-8080 (Online) & \\
\hline $\begin{array}{l}\text { EXCELLENT } \\
\text { PUBLISHERS }\end{array}$ & Journal homepage: www.ijcrbp.com & \\
\hline
\end{tabular}

Original Research Article

doi: https://doi.org/10.20546/ijcrbp.2018.511.003

\title{
Study on Thyroid Function Tests in Hemodialysis Patients of Iraq
}

\author{
Mays T. Abdalla ${ }^{*}$, Mohammed B. Hassan ${ }^{2}$ and Suhban S. Al-Mallah \\ ${ }^{1}$ College of Biotechnology/Al-Nahrain University, Baghdad, Iraq \\ ${ }^{2}$ Al-Yarmouk Teaching Hospital, Baghdad, Iraq \\ *Corresponding author.
}

\begin{tabular}{l} 
A r ticle In fo \\
\hline Date of Acceptance: \\
20 October 2018 \\
Date of Publication: \\
06 November 2018
\end{tabular}

Keywords

Chronic kidney disease

Serum albumen

Serum protein

Thyroid function

Thyroid hormones

\begin{abstract}
This study was designed to find the frequency of different abnormalities that can be observed in the results of thyroid function tests in patients with chronic renal failure, who are on hemodialysis, to assess the effect of having chronic renal failure on these frequencies, and to assess effect of age, duration of chronic renal failure, total serum protein level and serum albumin level of the results of thyroid function tests in patients with chronic renal failure, who are on hemodialysis. So that 35 patients with chronic renal failure and on hemodialysis had been randomly selected from those who attended the hemodialysis unit at Al-Yarmouk Teaching Hospital during the period from July 2016 to February 2017. Age and sex matched control had been selected randomly (35 patients).detailed questionnaire had been applied containing information about the personal information and risk factors. All of the patients investigated for thyroid function tests and total serum protein and serum albumin levels. This study had shown there is general tendency of all thyroid function tests to be low but with the normal range, this tendency had been shown according to age, duration of chronic renal failure, level of serum albumin and total serum protein. Lower T3 levels are associated statistically with older age, and lower serum albumin levels. Lower TSH is associated with older age and higher total serum protein levels.
\end{abstract}

\section{Introduction}

Thyroid hormones are necessary for growth, development, differentiation and metabolism of virtually all tissues of vertebrates (Miulescu et al., 2014). The growth and development of the kidney and the maintenance of water and electrolyte homeostasis thyroid hormones have important role on it (Punekar et al., 2017). Instead, kidney plays an important role in the metabolism, degradation and excretion of thyroid hormone. The kidney contributes to the iodine clearance primarily by glomerular filtration. Thus iodide concentrations are elevated in patients with chronic kidney disease (CKD) but not correlated with the degree of kidney failure (Mariani and Berns, 2012). The excess of inorganic iodide can possibly block thyroid hormone production by affecting the pituitary- 
thyroid axis and peripheral metabolism of thyroid hormones. Such variations explain higher frequency of hypothyroidism in patients with chronic kidney disease. Therefore, Thyroid dysfunction is a usually seen endocrine abnormality among CKD patients (Carrero et al., 2007). Previous studies have shown that CKD patients have low triiodothyronine (T3), normal or reduced thyroxine (T4) levels, and consequently elevated thyroid-stimulating hormone (TSH), Most patients with end stage renal disease have decreased plasma levels of free triidothyronine (T3), which reflect diminished conversion of $\mathrm{T} 4$ (thyroxin) to $\mathrm{T} 3$ in the periphery. This abnormality is not associated with increased conversion of T4 to the metabolically inactive reverse T3 (rT3), since plasma rT3 levels are typically normal. This finding differentiates the uremic patient from patients with chronic illness (Kaptein et al., 1988). In the end situation, the conversion of $\mathrm{T} 4$ to $\mathrm{T} 3$ is similarly reduced, but the generation of rT3 from T4 is enhanced. The plasma concentration of thyroid stimulating hormone (TSH) is usually normal in chronic renal failure. Nevertheless, the TSH response to exogenous thyrotropin-releasing hormone (TRH) is frequently blunted and delayed, with a extended time required to return to baseline levels (Swaminathan et al., 2016). Reduced renal clearance may contribute to delayed recovery, since TSH and TRH are usually cleared by the kidney. Though, the blunted hormone response also suggests disordered function at the hypothalamicpituitary level that can be prompted by uremic toxins. When compared to normal, patients with chronic renal failure have an attenuated rise in TSH levels during the evening hours and the normally pulsatile secretion of TSH is smaller in amplitude (Shamsuddinn, 2015).

There is considerable clinical overlap between chronic renal failure and hypothyroidism. Furthermore, to low total and plasma free T3 levels, there are a number of symptoms that are common to both conditions including cold intolerance, puffy appearance, dry skin, lethargy, fatigability, and constipation. Additionally, the frequency of goiter is markedly increased in end-stage renal disease (Lo et al., 2017).

\section{Patients and methods}

This study is a cross sectional study that enrolled 35 patients with chronic renal failure and on hemodialysis had been randomly selected from those who attended the hemodialysis unit at AlYarmouk Teaching Hospital during the period from July 2016 to February 2017, Age and sex matched control had been selected randomly (35 patients). detailed questionnaire had been applied containing information about the personal information and risk factors. All of the patients investigated for thyroid function tests and total serum protein and serum albumin levels. Thyroid function testing had been performed by (T3 (125I) RIA KIT REF: RK6CT1), T4 (125I) RIA KIT REF: RK-5CT1), Turbo TSH (125I) IRMI KIT REF: RK-1CT1), respectively. These systems provide direct quantitative in vitro determination of L-3, 5, 3triiodothyronine (T3), thyroxin (T4), and human thyroid stimulating hormone (TSH) in human serum. Patients were on regular hemodialysis, samples of blood were taken before starting hemodialysis sessions to avoid artifactual results caused by heparin. We made sure that all patients and controls did not receive furosemide before taking blood samples. The collected data had been processed using the software "Statistical package for Social Sciences", SPSS, version 13. All the analyzed data had been expressed in term of means \pm SD, and tabulated in form of frequency distribution tables and graphs. Statistical analysis is carried out using the software mentioned above (SPSS), and applying the required statistical significance testing according to the type of data to be assessed. We used analysis of variance (ANOVA) test and student's t-test as required and $p$-value of $<0.05$ had been considered as the level of significant association or difference.

\section{Results}

This study had enrolled 35 patients with chronic renal failure and on hemodialysis, whose age ranged between 19-60 years old with a mean of $38.69 \pm 10.75$ years old. Twenty three patients ( $65.7 \%$ of the sample) were 40 years old or younger 
and only 2 patients (5.7\% of the sample) were 60 years old or older. Nineteen patients $(54.3 \%$ of the sample) were male patients. Table (1) shows patients distribution according to their age and gender. The patients who had been included in this study had CRF for a mean duration of $6.6 \pm 3.1$ years (range: 2-14 years). Fifteen patients (42.9\% of the sample) were on CRF, for 5 years or less, while 8 patients $(22.9 \%$ of the sample) were on CRF, for 10 years or more. Table (2) shows patients distribution according to the duration of the CRF. The mean levels of T3, total T4, and TSH were $1.73 \pm 0.77 \mathrm{nmol} / \mathrm{l}($ range $0.6-3.5), 85.54 \pm 23.12$ $\mathrm{nmol} / \mathrm{l}$ (range $41-133 \mathrm{nmol} / \mathrm{l}$ ) and $2.93 \pm 2.32 \mathrm{miu} / \mathrm{ml}$ (range $0.32-8.2 \mathrm{miu} / \mathrm{ml}$ ), respectively. Twenty one patients $(60 \%$ of the sample) had T3 level of less than $2 \mathrm{nmol} / \mathrm{l}$. Table (4) shows patients distribution according to their total T4 level. Sixteen patients (45.8\% of the sample) had TSH level of less than 2 $\mathrm{min} / \mathrm{ml}$. Table (5) and figure (5) show patient's distribution according to their TSH level. Statistical analysis showed that the mean serum T3, which had been observed in patients with chronic renal failure, is statistically lower than the mean of serum T3 in the control group (calculated $\mathrm{t}=3.8, \mathrm{p}$ value $=$ 0.031). No significant difference had been noticed between the mean of serum TT4,TSH between the sample and control group ( $p$-value $>0.05$ ).

\section{Age and thyroid function in patients with CRF}

This study showed that the mean serum T3 level was $1.88 \pm 0.77 \mathrm{nmol} / \mathrm{l}$ in those patients aging 40 year old or younger, while it was $1.57 \pm 0.71 \mathrm{nmol} / \mathrm{l}$ and $0.71 \pm 0.02 \mathrm{nmol} / \mathrm{l}$ in patients aging 41-59 year old and 60 year old or older, respectively. In term of frequency, this study showed that $52.2 \%$ of those with age of 40 years old or younger had serum T3 level of less than $2 \mathrm{nmol} / \mathrm{l}$, with only two patients (8.7\%) having serum T3 level of less than $1 \mathrm{nmol} / 1$. while, $70 \%$ and $100 \%$ of those with the other two older age groups had serum T3 level of less than 2nmol/l, respectively. After doing statistical analysis using analysis of variance test (one way ANOVA), it had been shown that statistically significant difference was present between the means of serum T3 level in these 3 age groups (calculated $\mathrm{F}=3.987, \mathrm{p}$ value $=0.007)$. Figure (1) shows the difference in mean T3 level between different age groups. In regard to TT4 level, this study indicated that mean TT4 was $86.5 \pm 24.4$ $\mathrm{nmol} / \mathrm{l}$ and $81.3 \pm 22.3 \mathrm{nmol} / \mathrm{l}$ in those aging 40 year old or younger and 41-59 years old, respectively. $78.2 \%$ of those aging 40 or younger and $100 \%$ of those 60 year-old or older had serum TT4 level of less than 100nmol/l. Figure(2) shows the difference in the mean TT4 level between different age groups. Statistical analysis using ANOVA showed no significant difference in the mean of serum TT4 of different age groups (calculate $\mathrm{F}=4.103$, p value $=0.060$ ). This study showed that mean serum TSH was $3.0 \pm 2.4$ and $0.36 \pm 0.05 \mathrm{miu} / \mathrm{ml}$ in patients whose age was 40 year old or younger and those with 60 years old or older, respectively. Statistical analysis indicated that significant difference present between the means of three age groups (calculated $\mathrm{F}=4.266$, $\mathrm{p}$ value $=0.008)$. Figure $(3)$ shows the difference in the mean serum TSH level in different age groups. Table (6) shows patients distribution according to age, serum T3 level, serum TT4 level and serum TSH level respectively.

\section{Duration of CRF and Thyroid function test}

The mean serum T3 level was $1.62 \pm 0.57 \mathrm{nmol} / \mathrm{l}$, and $1.3 \pm 0.61 \mathrm{nmol} / \mathrm{l}$ in patients with $\mathrm{CRF}$ for 5 years or less and 6-9 years, respectively, $88.3 \%$ of the latter group (10 patients) and $60 \%$ of the former group (9 patients) had serum T3 level of less than 2 nmol/l. No significant differences had been found between the means of serum T3 level in patients with different duration of CRF (calculated $\mathrm{F}=$ $1.070, \mathrm{p}$ value $=0.463$ ). Figure (4) shows the association between the duration of CRF and serum T3 level. The mean serum TT4 was $84.8 \pm 23.9$ $\mathrm{nmol} / \mathrm{l}$ and $77.6 \pm 22.1 \mathrm{nmol} / \mathrm{l}$ in patients with CRF for 5 years or less and 6-9 years, respectively. No statistically significant difference had noticed in different duration of CRF (calculated $F=3.552$, $p$ value $=0.081)$. Figure (5) shows the association between the duration of CRF and patients serum TT4 level. Patients with CRF for 5 years or more had mean serum TSH value of $2.6 \pm 2.5 \mathrm{miu} / \mathrm{ml}$, 
while those with 6-9 years had mean serum TSH value of $2.5 \pm 2.2 \mathrm{miu} / \mathrm{ml}$. statistical analysis revealed no significant effect of duration of CRF on the mean of the serum TSH level (calculated $\mathrm{F}=$ $1.521, \mathrm{p}$ value $=0,238$ ). Table (7) show patient's distribution according to the duration of CRF and serum T3, TT4 and TSH levels. Figure (6) shows the association between the duration of CRF and patients serum TSH level.

\section{Serum albumin level and thyroid function test}

The mean serum T3 level was $1.4 \pm 0.6$ and $2.1 \pm$ 0.4 in patients with serum Albumin level of $<35 \mathrm{~g} / \mathrm{l}$ and $40 \mathrm{~g} / 1$ and more, respectively. Only 4 patients with serum albumin of less than $35 \mathrm{~g} / \mathrm{l}(30.8 \%)$ had serum T3 level of $2 \mathrm{nmol} / \mathrm{l}$ or more, while 6 patients with serum albumin level of $40 \mathrm{~g} / \mathrm{l}$ or more (66.7) had similar serum T3 level. Statistical analysis indicated the presence of significant difference the mean serum T3 level according to patient's serum albumin. Figure (7) shows the association between serum T3level and serum albumin. This study showed that mean serum TT4 $83.6 \pm 26.7 \mathrm{nmol} / \mathrm{l}$ in patients with serum albumin level of $<35 \mathrm{~g} / \mathrm{l}$, compared to mean serum TT4 level of $86.6 \pm 21.5 \mathrm{nmol} / \mathrm{l}$. No statistically significant difference had been observed in the mean TT4 level in patients with difference serum albumin levels (calculated $\mathrm{F}=1.685, \mathrm{p}$ value $=$ $0.295)$. The mean TSH level was $2.2 \pm 1.3 \mathrm{miu} / \mathrm{ml}$ and $2.9 \pm 2.3 \mathrm{miu} / \mathrm{ml}$ in patients with serum albumin $<35 \mathrm{~g} / \mathrm{l}$, and $40 \mathrm{~g} / \mathrm{l}$ respectively. $77.8 \%$ of the latter group (7 patients) had serum TSH level of more than $2 \mathrm{miu} / \mathrm{ml}$. No statistically significant association had been observed between serum albumin and serum TSH level (calculated $\mathrm{F}=$ $1.516, \mathrm{p}$ value $=0.240)$. Table $(8)$ shows patients distribution according to their serum albumin level and the serum levels of T3, TT4, and TSH.

\section{Total serum protein and thyroid functions test}

The mean serum T3 level was $1.63 \pm 0.8 \mathrm{~mol} / 1$, and $1.99 \pm 0.7 \mathrm{nmol} / \mathrm{l}$ in patients with total serum protein level of less than $65 \mathrm{~g} / \mathrm{l}$ and $65 \mathrm{~g} / \mathrm{l}$ or more, respectively. No significant association between total serum protein and serum T3 level (calculated $\mathrm{t}$ $=1.746, \mathrm{p}$ value $=0.151)$. Statistical analysis showed no significant association between the serum TT4 and total serum protein level. (Calculated $\mathrm{t}=2.3$, p value $=0.09$ ). Statistical analysis indicated that significant statistical association was present between the total serum protein and serum TSH level (calculated $\mathrm{t}=3.8, \mathrm{p}$ value $=0.03)$. Figure $(8)$ shows the association between serum TSH levels and total serum protein. Table (9) shows patients distribution according to the level of total serum protein and serum T3,TT4, and TSH. Hypertension had been observed in 19 patients (54.3\% of the sample). No one had been shown to have goiter. Table (10) shows the frequency of different risk factors. Wight loss had been detected in 13 patients (37.1\% of the sample). Table (11) shows the frequency of different symptoms and signs.

Table 1. Age and gender distribution of the sample.

\begin{tabular}{lllllll}
\hline \multirow{2}{*}{ Age gro`up } & Male & \multicolumn{3}{c}{ Female } & Total & \\
\cline { 2 - 7 } & No. & $\%$ & No. & \% & No. & \% \\
\hline$\leq 40$ years & 13 & $68.0 \%$ & 10 & 62.5 & 23 & $65.7 \%$ \\
$41-59$ years & 6 & $31.6 \%$ & 4 & $25.0 \%$ & 10 & $28.6 \%$ \\
$\geq 60$ years & 0 & $0 \%$ & 2 & $12.5 \%$ & 2 & $5.7 \%$ \\
Total & 19 & $100.0 \%$ & 16 & $100.0 \%$ & 35 & $100.0 \%$ \\
\hline
\end{tabular}

Table 2. Patient's distribution according to the duration of CRF.

\begin{tabular}{lll}
\hline Duration of CRF & No. & \% \\
\hline 5 years & 15 & 42.9 \\
$6-9$ years & 12 & 34.3 \\
$\geq 10$ years & 8 & 22.9 \\
Total & 35 & 100.0 \\
\hline
\end{tabular}


Table 3. Patient's distribution according to their serum T3 levels.

\begin{tabular}{lll}
\hline Serum T3 level (nmol/l) & No. & \% \\
\hline $0.55-0.99 \mathrm{nmol} / 1$ & 7 & 20.0 \\
$1.0-1.99 \mathrm{nmol} / 1$ & 14 & 40.0 \\
$2.0-2.99 \mathrm{nmol} / 1$ & 12 & 34.3 \\
$\geq 3.0 \mathrm{nmol} / 1$ & 2 & 5.7 \\
Total & 35 & 100.0 \\
\hline
\end{tabular}

Table 4. Patient's distribution according to their total T4 level.

\begin{tabular}{lll}
\hline Total T4 level & No. & \% \\
\hline$<55 \mathrm{nmol} / \mathrm{l}$ & 4 & 11.4 \\
$55-99 \mathrm{nmol} / \mathrm{l}$ & 22 & 62.9 \\
$100-149 \mathrm{nmol} / \mathrm{l}$ & 9 & 25.7 \\
Total & 35 & 100 \\
\hline
\end{tabular}

Table 5. Patient's distribution according to their TSH level.

\begin{tabular}{lll}
\hline TSH level & No. & \% \\
\hline$<1 \mathrm{miu} / \mathrm{ml}$ & 8 & 22.9 \\
$1-1.9 \mathrm{miu} / \mathrm{ml}$ & 8 & 22.9 \\
$2-3.75 \mathrm{miu} / \mathrm{ml}$ & 11 & 31.4 \\
$\geq 3.76 \mathrm{miu} / \mathrm{ml}$ & 8 & 22.9 \\
Total & 35 & 100.0 \\
\hline
\end{tabular}

Table 6. Patient's distribution according to their age and results of thyroid function test.

\begin{tabular}{|c|c|c|c|c|c|c|c|}
\hline \multirow{2}{*}{\multicolumn{2}{|c|}{ Thyroid function test }} & \multicolumn{6}{|c|}{ Age groups } \\
\hline & & \multicolumn{2}{|c|}{$\begin{array}{l}\leq 40 \text { years } \\
(n=23)\end{array}$} & \multicolumn{2}{|c|}{$\begin{array}{l}\text { 41-59 years } \\
(n=10)\end{array}$} & \multicolumn{2}{|c|}{$\begin{array}{l}\geq 60 \text { years } \\
(n=2)\end{array}$} \\
\hline & & No. & $\%$ & No. & $\%$ & No. & $\%$ \\
\hline \multirow[t]{5}{*}{ T3 level } & $0.55-0.99 \mathrm{nmol} / 1$ & 2 & $8.7 \%$ & 3 & $30.0 \%$ & 2 & $100.0 \%$ \\
\hline & $1.0-199 \mathrm{nmol} / 1$ & 10 & $43.5 \%$ & 4 & $40.0 \%$ & 0 & $.0 \%$ \\
\hline & $2.0-2.99 \mathrm{nmol} / \mathrm{l}$ & 9 & $39.1 \%$ & 3 & $30.0 \%$ & 0 & $.0 \%$ \\
\hline & $\geq 3.0 \mathrm{nmol} / 1$ & 2 & $8.7 \%$ & 0 & $0 \%$ & 0 & $.0 \%$ \\
\hline & Mean \pm SD & \multicolumn{2}{|c|}{$1.88 \pm 0.7 \mathrm{nmol} / \mathrm{l}$} & \multicolumn{2}{|c|}{$1.57 \pm 0.7 \mathrm{nmol} / \mathrm{l}$} & \multicolumn{2}{|c|}{$0.71 \pm 0.02 \mathrm{nmol} / 1$} \\
\hline \multirow[t]{6}{*}{ TT4 level } & $<55 \mathrm{nmol} / \mathrm{l}$ & 3 & $13.0 \%$ & 1 & $10.0 \%$ & 0 & $.0 \%$ \\
\hline & $55-99 \mathrm{nmol} / 1$ & 15 & $65.2 \%$ & 5 & $50.0 \%$ & 2 & $100.0 \%$ \\
\hline & $100-149 \mathrm{nmol} / \mathrm{l}$ & 5 & $21.7 \%$ & 4 & $40.0 \%$ & 0 & $0 \%$ \\
\hline & $150-169 \mathrm{nmol} / \mathrm{l}$ & 0 & $0 \%$ & 0 & $0 \%$ & 0 & $0 \%$ \\
\hline & $\geq 170 \mathrm{nmol} / 1$ & 0 & $0 \%$ & 0 & $0 \%$ & 0 & $0 \%$ \\
\hline & Mean \pm SD & \multicolumn{2}{|c|}{$86.5 \pm 24.4 \mathrm{nmol} / \mathrm{l}$} & \multicolumn{2}{|c|}{$81.3 \pm 22.3 \mathrm{nmol} / \mathrm{l}$} & \multicolumn{2}{|c|}{$83.0 \pm 2.8 \mathrm{nmol} / \mathrm{l}$} \\
\hline \multirow[t]{5}{*}{ TSH level } & $<1 \mathrm{miu} / \mathrm{l}$ & 5 & $21.7 \%$ & 1 & $10.0 \%$ & 2 & $100.0 \%$ \\
\hline & $1-1.9 \mathrm{miu} / \mathrm{l}$ & 3 & $13.0 \%$ & 5 & $50.0 \%$ & 0 & $0 \%$ \\
\hline & $2-3.75 \mathrm{miu} / \mathrm{l}$ & 8 & $34.8 \%$ & 3 & $30.0 \%$ & 0 & $0 \%$ \\
\hline & $\geq 3.76 \mathrm{miu} / 1$ & 7 & $30.4 \%$ & 1 & $10.0 \%$ & 0 & $0 \%$ \\
\hline & Mean \pm SD & \multicolumn{2}{|c|}{$30 \pm 2.4 \mathrm{miu} / \mathrm{ml}$} & \multicolumn{2}{|c|}{$1.7 \pm 0.93 \mathrm{miu} / \mathrm{ml}$} & \multicolumn{2}{|c|}{$0.36 \pm 0.05 \mathrm{miu} / \mathrm{ml}$} \\
\hline
\end{tabular}


Table 7. Patient's distribution according to duration of CRF and results of thyroid function test.

\begin{tabular}{|c|c|c|c|c|c|c|c|}
\hline \multirow{3}{*}{\multicolumn{2}{|c|}{ Thyroid function test }} & \multicolumn{6}{|c|}{ Duration of CRF } \\
\hline & & \multicolumn{2}{|c|}{$\begin{array}{l}\leq 5 \text { years } \\
(n=15)\end{array}$} & \multicolumn{2}{|c|}{$\begin{array}{l}\text { 6-9 years } \\
(n=12)\end{array}$} & \multicolumn{2}{|c|}{$\begin{array}{l}\geq 10 \text { years } \\
(n=8)\end{array}$} \\
\hline & & No. & $\%$ & No. & $\%$ & No. & $\%$ \\
\hline \multirow[t]{5}{*}{ T3 level } & $0.55-0.99 \mathrm{nmol} / 1$ & 3 & $20.0 \%$ & 4 & $33.3 \%$ & 0 & $0 \%$ \\
\hline & $1.0-199 \mathrm{nmol} / \mathrm{l}$ & 6 & $40.0 \%$ & 6 & $50.0 \%$ & 2 & $25.0 \%$ \\
\hline & $2.0-2.99 \mathrm{nmol} / \mathrm{l}$ & 6 & $40.0 \%$ & 2 & $16.7 \%$ & 4 & $50.0 \%$ \\
\hline & $\geq 3.0 \mathrm{nmol} / 1$ & 0 & $0 \%$ & 0 & $0 \%$ & 2 & $25.0 \%$ \\
\hline & Mean \pm SD & \multicolumn{2}{|c|}{$1.62 \pm 0.57 \mathrm{nmol} / \mathrm{l}$} & \multicolumn{2}{|c|}{$1.3 \pm 0.61 \mathrm{nmol} / \mathrm{l}$} & \multicolumn{2}{|c|}{$2.5 \pm 0.7 \mathrm{nmol} / 1$} \\
\hline \multirow[t]{6}{*}{ TT4 level } & $<55 \mathrm{nmol} / 1$ & 2 & $13.3 \%$ & 2 & $16.7 \%$ & 0 & $0 \%$ \\
\hline & $55-99 \mathrm{nmol} / \mathrm{l}$ & 10 & $66.7 \%$ & 8 & $66.7 \%$ & 4 & $50.0 \%$ \\
\hline & $100-149 \mathrm{nmol} / \mathrm{l}$ & 3 & $20.0 \%$ & 2 & $16.7 \%$ & 4 & $50.0 \%$ \\
\hline & $150-169 \mathrm{nmol} / \mathrm{l}$ & 0 & $0 \%$ & 0 & $0 \%$ & 0 & $0 \%$ \\
\hline & $\geq 170 \mathrm{nmol} / 1$ & 0 & $0 \%$ & 0 & $0 \%$ & 0 & $0 \%$ \\
\hline & Mean \pm SD & \multicolumn{2}{|c|}{$86.5 \pm 24.4 \mathrm{nmol} / \mathrm{l}$} & \multicolumn{2}{|c|}{$81.3 \pm 22.3 \mathrm{nmol} / \mathrm{l}$} & \multicolumn{2}{|c|}{$95.5 \pm 19.9 \mathrm{nmol} / \mathrm{l}$} \\
\hline \multirow[t]{5}{*}{ TSH level } & $<1 \mathrm{miu} / \mathrm{l}$ & 4 & $26.7 \%$ & 3 & $25.0 \%$ & 1 & $12.5 \%$ \\
\hline & $1-1.9 \mathrm{miu} / \mathrm{l}$ & 3 & $20.0 \%$ & 3 & $25.0 \%$ & 2 & $25.0 \%$ \\
\hline & $2-3.75 \mathrm{miu} / 1$ & 5 & $33.3 \%$ & 2 & $16.7 \%$ & 4 & $50.0 \%$ \\
\hline & $\geq 3.76 \mathrm{miu} / 1$ & 3 & $20.0 \%$ & 4 & $33.3 \%$ & 1 & $12.5 \%$ \\
\hline & Mean \pm SD & \multicolumn{2}{|c|}{$2.6 \pm 2.5 \mathrm{miu} / \mathrm{ml}$} & \multicolumn{2}{|c|}{$2.5 \pm 2.2 \mathrm{miu} / \mathrm{ml}$} & \multicolumn{2}{|c|}{$2.01 \pm 1.09 \mathrm{miu} / \mathrm{ml}$} \\
\hline
\end{tabular}

Table 8. Patient's distribution according to their serum albumin and results of thyroid function test.

\begin{tabular}{|c|c|c|c|c|c|c|c|}
\hline \multirow{2}{*}{\multicolumn{2}{|c|}{ Thyroid function test }} & \multicolumn{6}{|c|}{ Serum albumin } \\
\hline & & \multicolumn{2}{|c|}{$\begin{array}{l}\leq 35 \text { years } \\
(n=13)\end{array}$} & \multicolumn{2}{|c|}{$\begin{array}{l}\text { 35-39 years } \\
(n=13)\end{array}$} & \multicolumn{2}{|c|}{$\begin{array}{l}\geq 40 \text { years } \\
(n=9)\end{array}$} \\
\hline & & No. & $\%$ & No. & $\%$ & No. & $\%$ \\
\hline \multirow[t]{5}{*}{ T3 level } & $0.55-0.99 \mathrm{nmol} / 1$ & 5 & $38.5 \%$ & 2 & $15.4 \%$ & 0 & $0 \%$ \\
\hline & $1.0-199 \mathrm{nmol} / 1$ & 4 & $30.8 \%$ & 7 & $53.8 \%$ & 3 & $33.3 \%$ \\
\hline & $2.0-2.99 \mathrm{nmol} / \mathrm{l}$ & 4 & $30.8 \%$ & 2 & $15.4 \%$ & 6 & $66.7 \%$ \\
\hline & $\geq 3.0 \mathrm{nmol} / 1$ & 0 & $0 \%$ & 2 & $15.4 \%$ & 0 & $0 \%$ \\
\hline & Mean \pm SD & \multicolumn{2}{|c|}{$1.4 \pm 0.6 \mathrm{nmol} / 1$} & \multicolumn{2}{|c|}{$1.8 \pm 1.9 \mathrm{nmol} / 1$} & \multicolumn{2}{|c|}{$2.1 \pm 0.4 \mathrm{nmol} / 1$} \\
\hline \multirow[t]{6}{*}{ TT4 level } & $<55 \mathrm{nmol} / \mathrm{l}$ & 2 & $15.4 \%$ & 1 & $7.7 \%$ & 1 & $11.1 \%$ \\
\hline & $55-99 \mathrm{nmol} / \mathrm{l}$ & 7 & $53.8 \%$ & 10 & $76.9 \%$ & 5 & $55.6 \%$ \\
\hline & $100-149 \mathrm{nmol} / \mathrm{l}$ & 4 & $30.8 \%$ & 2 & $15.4 \%$ & 3 & $33.3 \%$ \\
\hline & $150-169 \mathrm{nmol} / \mathrm{l}$ & 0 & $0 \%$ & 0 & $0 \%$ & 0 & $0 \%$ \\
\hline & $\geq 170 \mathrm{nmol} / 1$ & 0 & $0 \%$ & 0 & $0 \%$ & 0 & $0 \%$ \\
\hline & Mean \pm SD & \multicolumn{2}{|c|}{$83.6 \pm 26.7 \mathrm{nmol} / 1$} & \multicolumn{2}{|c|}{$84.7 \pm 21.3 \mathrm{nmol} / \mathrm{l}$} & \multicolumn{2}{|c|}{$86.6 \pm 21.5 \mathrm{nmol} / \mathrm{l}$} \\
\hline \multirow[t]{5}{*}{ TSH level } & $<1 \mathrm{miu} / 1$ & 2 & $15.4 \%$ & 5 & $38.5 \%$ & 1 & $11.1 \%$ \\
\hline & $1-1.9 \mathrm{miu} / 1$ & 4 & $30.8 \%$ & 3 & $23.1 \%$ & 1 & $11.1 \%$ \\
\hline & $2-3.75 \mathrm{miu} / 1$ & 4 & $30.8 \%$ & 2 & $15.4 \%$ & 5 & $55.6 \%$ \\
\hline & $\geq 3.76 \mathrm{miu} / 1$ & 3 & $23.1 \%$ & 3 & $23.1 \%$ & 2 & $22.2 \%$ \\
\hline & Mean \pm SD & \multicolumn{2}{|c|}{$2.2 \pm 1.3 \mathrm{miu} / \mathrm{ml}$} & \multicolumn{2}{|c|}{$2.5 \pm 2.7 \mathrm{miu} / \mathrm{ml}$} & \multicolumn{2}{|c|}{$2.9 \pm 2.3 \mathrm{miu} / \mathrm{ml}$} \\
\hline
\end{tabular}


Table 9. Patient's distribution according to their total serum protein and results of thyroid function test.

\begin{tabular}{|c|c|c|c|c|c|}
\hline \multirow{2}{*}{\multicolumn{2}{|c|}{ Thyroid function test }} & \multicolumn{4}{|c|}{ Total serum protein } \\
\hline & & \multicolumn{2}{|c|}{$\begin{array}{l}\leq 65 \mathrm{~g} / \mathrm{l} \\
(\mathrm{n}=26)\end{array}$} & \multicolumn{2}{|c|}{$\geq 65 \mathrm{~g} / \mathrm{l}$} \\
\hline & & Count & Column \% & No. & $\%$ \\
\hline \multirow[t]{5}{*}{ T3 level } & $0.55-0.99 \mathrm{nmol} / 1$ & 6 & $23.1 \%$ & 1 & $11.1 \%$ \\
\hline & $1.0-199 \mathrm{nmol} / \mathrm{l}$ & 12 & $46.2 \%$ & 2 & $22.2 \%$ \\
\hline & $2.0-2.99 \mathrm{nmol} / \mathrm{l}$ & 6 & $23.1 \%$ & 6 & $66.7 \%$ \\
\hline & $\geq 3.0 \mathrm{nmol} / 1$ & 2 & $7.7 \%$ & 0 & $0 \%$ \\
\hline & Mean \pm SD & \multicolumn{2}{|c|}{$1.63 \pm 0.8 \mathrm{nmol} / \mathrm{l}$} & \multicolumn{2}{|c|}{$1.99 \pm 0.7 \mathrm{nmol} / 1$} \\
\hline \multirow[t]{6}{*}{ TT4 level } & $<55 \mathrm{nmol} / \mathrm{l}$ & 2 & $7.7 \%$ & 2 & $22.2 \%$ \\
\hline & $55-99 \mathrm{nmol} / \mathrm{l}$ & 18 & $69.2 \%$ & 4 & $44.4 \%$ \\
\hline & $100-149 \mathrm{nmol} / \mathrm{l}$ & 6 & $23.1 \%$ & 3 & $33.3 \%$ \\
\hline & $150-169 \mathrm{nmol} / \mathrm{l}$ & 0 & $0 \%$ & 0 & $0 \%$ \\
\hline & $\geq 170 \mathrm{nmol} / \mathrm{l}$ & 0 & $0 \%$ & 0 & $0 \%$ \\
\hline & Mean \pm SD & \multicolumn{2}{|c|}{$84.7 \pm 21.2 \mathrm{nmol} / 1$} & \multicolumn{2}{|c|}{$85.8 \pm 28.5 \mathrm{nmol} / 1$} \\
\hline \multirow[t]{5}{*}{ TSH level } & $<1 \mathrm{miu} / \mathrm{l}$ & 7 & $26.9 \%$ & 1 & $11.1 \%$ \\
\hline & $1-1.9 \mathrm{miu} / \mathrm{l}$ & 7 & $26.9 \%$ & 1 & $11.1 \%$ \\
\hline & $2-3.75 \mathrm{miu} / 1$ & 7 & $29.9 \%$ & 4 & $44.4 \%$ \\
\hline & $\geq 3.76 \mathrm{miu} / 1$ & 5 & $19.2 \%$ & 3 & $33.3 \%$ \\
\hline & Mean \pm SD & \multicolumn{2}{|c|}{$3.6 \pm 2.8 \mathrm{miu} / \mathrm{ml}$} & \multicolumn{2}{|c|}{$2.1 \pm 1.7 \mathrm{miu} / \mathrm{ml}$} \\
\hline
\end{tabular}

Table 10. Frequency of different risk factors that had been looked for in this study.

\begin{tabular}{lll}
\hline Risk factors & No. & \% \\
\hline Hypertension & 19 & $54.3 \%$ \\
Diabetes mellitus & 0 & $0 \%$ \\
Ischemic heart disease & 3 & $8.6 \%$ \\
Personal and family history of goiter or altered thyroid function & 2 & $5.7 \%$ \\
Personal and family history of other autoimmune diseases & 0 & $0 \%$ \\
History of intake of iodine containing drugs or drugs that effect thyroid function & 0 & $0 \%$ \\
History of thyroid surgery or radioactive iodine intake & 0 & $0 \%$ \\
\hline
\end{tabular}

Table 11. Frequency of the observed physical signs and symptoms that had been noticed in sample of this study.

\begin{tabular}{lll}
\hline Physical signs and symptoms & No. & \% \\
\hline Constipation & 4 & 11.4 \\
Menstrual disturbances & 8 & 22.9 \\
Weight loss & 13 & 37.1 \\
Heat intolerance & 1 & 2.9 \\
Frequent bowel motion & 1 & 2.9 \\
Palpitation & 6 & 17.1 \\
Tremor & 10 & 28.6 \\
Sweating & 1 & 2.9 \\
tachycardia & 4 & 11.4 \\
\hline
\end{tabular}




\section{Discussion}

Regarding results of thyroid function tests in patients with uremia and on hemodialysis, this study had shown that statistically significant lower mean of total T3 levels had been detected in comparison with that observed in the age and sex matched control. Taking into consideration that the T3 levels which have noticed in patients with CRF were within normal range but more in the lower limits of the normal, and no case of hypothyroidism had been diagnosed in the sample under study. While, no statistically significant difference between the mean values of serum TT4 and serum TSH had been detected when comparing these means with that observed in the control group. This finding of low serum T3 and relatively normal T4 and TSH is consistent with the results of most similar studies. Lim et al. (1985), Enia et al. (2007) and Paudel (2014) found that low T3 syndrome is the most frequent finding in patients which chronic renal failure that are on different kinds of replacement therapy. Other studies indicated that patients with chronic renal failure display alteration in thyroid function of various severities ranging from low-T3 syndrome to subclinical and frank hypothyroidism (Rhee et al., 2014). Our study is different from the latter groups of studies in that no case of subclinical or frank hypothyroidism had been detected in the sample of our study and the entire sample had mostly low-T3 syndrome rather than any other kind of thyroid function alteration. Intensive studies in the 1980s and 2010s revealed that renal insufficiency affects thyroid function in multiple ways, including altered peripheral hormone metabolism, disturbed binding to proteins, reduction in tissue thyroid hormone content, and iodine accumulation in the thyroid glands. Furthermore, uremic patients have a variety of nonrenal, non-thyroidal disorders that affect thyroid hormone metabolism such as diabetes mellitus, infections, and malnutrition and they are often treated by drugs that interfere with thyroid function. In addition, Brough and Jones (2006) found that the use of iodine as a disinfectant might induce suppression of thyroid hormone synthesis. It is important to mention here that no one of those included in our sample had diabetes, however, detection of infection and assessment of nutritional status did not been included in the study design. Currently, inflammation had been emerged as one of the important causes of deranged thyroid function associated with chronic or acute nonthyroidal illness (Bartalena et al., 1994). But to study this important risk factor, we are in need for more sophisticated investigations that are not currently available widely in our country, like measuring the iterleukine-6 levels and other inflammatory mediators. This study showed that no one of patients who had been included in the study had goiter. In contrast, thyroid gland size is often increased in patients with chronic renal. Ramirez $G$ found that most patients of chronic renal failure have increased thyroid size without any clear idea about the etiology of this finding and suggestion that renal failure is associated with the accumulation of an unidentified goitrogens (Ramirez, 1994). This controversy between our results and other studies can be explained by the methods used by the authors of the other studies like the use of ultrasound scanning as a method for accurate detection of the size of thyroid gland, in addition to the fact that the frequency of goiter is variable between different populations depending on their nutritional habits and geographical area they live in.

Our study tried to assess the effect of age, duration of chronic renal failure, serum albumin level and total serum protein level. It had been shown that there is a statistically significant association between lower T3 levels and increasing age. Similarly, Enia et al. (2007) found that free T3 levels were inversely related to age. Another interesting finding had been shown in Enia's study, that when they classified their patients into three groups according to their concentration of Interleukine-6, it had been noticed that the mean age of the first group with plasma concentration of IL-6 $<5.9 \mathrm{pg} / \mathrm{ml}$ was $57+19$ year-old, while the mean age of the third group with IL-6 values of > $10.9 \mathrm{pg} / \mathrm{ml}$ was $72+11$, with statistically significant correlation between age and plasma level of IL-6. this finding suggests that older people with chronic 
renal failure might have higher degrees of inflammation and have higher levels of inflammatory mediators which are now considered as one of the emerging and important factors that are associated with the alteration in the thyroid function in patients with chronic renal failure (Enia et al., 2007). Although higher frequency of low T3 had been observed in patients with longer duration of hemodialysis and CRF, but no statistically significant association had been detected between longer duration and lower serum T3 levels. This finding is similar to what had been concluded from Pagliacci et al. (1987) study. They found that there is no association between starting the replacement therapy and its duration and having low serum T3 levels, with same tendency toward lower T3 values with longer duration. This tendency can be explained by the lower Glomerular filtration rate that might be present in patients with CRF for longer period. In addition, this insignificant association can be due to small sample size that this study had include, and larger sample size is required to clarify the effect of CRF duration on thyroid function test. Regarding the relationship between the results of thyroid function tests in patients with CRF and hemodialysis and total serum protein and serum albumin, this study had showed that despite the finding of modestly higher means which had been observed in patients with higher values of serum albumin and total serum protein, but the only statistically significant association had been observed between the mean serum T3 level and serum TSH in one hand and serum albumin and total serum protein in other hand, respectively. This finding of no significant association can be related to the small sample size as it had been mentioned earlier. Furthermore, although circulating thyroid hormones binding globuline and albumin levels are typically normal in uremia (in the absence of nephrotic syndrome), retained substances may inhibit hormone binding to these proteins. The interesting point to be mentioned here is that hemodialysis patients some transient elevation in serum T4 levels commonly occurs during hemodialysis, Herchman et al. (1972) found that this phenomenon is related to the use of heparin as a routine maneuver to prevent clotting in the dialysis tubing and that heparin interfere with T4 binding to thyroid hormone binding globuline.

\section{Conflict of interest statement}

Authors declare that they have no conflict of interest.

\section{References}

Bartalena, L., Brogioni, S., Grasso, L., Velluzzi, F., Martino, E., 1994. Relationship of the increased serum interleukin- 6 concentration to changes in thyroid function in non-thyroidal illness. J. Endocrinol. Invest. 17, 269-274.

Brough, R., Jones, C., 2006. Iatrogenic iodine as a cause of hypothyroidism in infants with end stage renal failure. Peadiatr. Nephrol. 3, 400402 .

Carrero, J.J., Qureshi, A.R., Axelsson, J., Yilmaz, M.I., Rehnmark, S., Witt, M.R., Bárány, P., Heimbürger, O., Suliman, M.E., Alvestrand, A., Lindholm, B., 2007. Clinical and biochemical implications of low thyroid hormone levels (total and free forms) in euthyroid patients with chronic kidney disease. J, Internal Med. 262(6), 690-701.

Enia, G., Panuccio, V., Cutrupi, S., Pizzini, P., Tripepi, G., Mallamaci, F., Zoccali, C., 2006. Subclinical hypothyroidism is linked to microinflammation and predicts death in continuous ambulatory peritoneal dialysis. Nephrol. Dial. Transplant. 22(2), 538-544.

Herschman, J. M., Jones, C. M., Bailey, A. L., 1972. Reciprocal changes in serum thyrotropin and free thyroxine produced by heparin. J. Clin. Endocrinol. Metab. 34, 574.

Kaptein, E.M., Quion-Verde, H.E.R.M.I.N.I.A., Chooljian, C.J., Tang, W.W., Friedman, P.E., Rodriquez, H.J. and Massry, S.G., 1988. The thyroid in end-stage renal disease. Medicine. 67(3), 187-197.

Lim, V. S., Flanigan, M. J., Zavala, D.C., 1985. Protective adaptation of low serum triiodothyronine in patients with chronic renal failure. Kidney Int. 28, 541.

Lo, J.C., Beck, G.J., Kaysen, G.A., Chan, C.T., 
Kliger, A.S., Rocco, M.V., Li, M., Chertow, G.M., FHN Study, 2017. Thyroid function in end stage renal disease and effects of frequent hemodialysis. Hemodial. Int. 21(4), 534-541.

Mariani, L. H., Berns, J. S., 2012. The renal manifestations of thyroid disease. J. Am. Soc. Nephrol. 23, 22-26.

Miulescu, R. D., Neamţu, M. C., Margină, D., Poiană, C., Păun, D. L., 2014. Associations between thyroid dysfunction and chronic kidney disease. Rom. J. Diabetes Nutr. Metab. Dis. 21(1), 37-42.

Pagliacci, M. C., Pelicci, G., Grignani, F., Giammartino, C., Fedeli, L., Carobi, C., Buoncristiani, U., Nicoletti, I., 1987. Thyroid function tests in patients undergoing maintenance dialysis: characterization of the 'low-T4 syndrome' in subjects on regular hemodialysis and continuous ambulatory peritoneal dialysis. Nephron. 46(3), 225-230.

Paudel, K., 2014. Prevalence and clinical characteristics of hypothyroidism in a population undergoing maintenance hemodialysis. J. Clin. Diagn. Res. 8(4), MC01.

Punekar, J., Singh, A.A., Malav, M.K., 2017. Study of thyroid function in patients with chronic kidney disease. Int. J. Health Sci. Res. 7, 68-72.

Ramirez, G., 1994. Abnormalities in the hypothalamic-hypophyseal axes in patients with chronic renal failure. Semin. Dial. 7, 138.

Rhee, C.M., Kalantar-Zadeh, K., Streja, E., Carrero, J.J., Ma, J.Z., Lu, J.L., Kovesdy, C.P., 2014. The relationship between thyroid function and estimated glomerular filtration rate in patients with chronic kidney disease. Nephrol. Dial. Transplant. 30(2), 282-287.

Shamsuddinn, M., 2015. Comparative study of thyroid abnormalities with severity of chronic renal failure. J. Evol. Med. Dental Sci. 4, 14039-14047.

Swaminathan, K., Rajesh, S., Avudaiappan, S., 2016. A study of thyroid function abnormalities in patients with chronic kidney disease. J. Dental Med. Sci. 15(8), 7-15.

\section{How to cite this article:}

Abdalla, M. T., Hassan, M. B., Al-Mallah, S. S., 2018. Study on thyroid function tests in hemodialysis patients of Iraq. Int. J. Curr. Res. Biosci. Plant Biol. 5(11), 34-43.

doi: https://doi.org/10.20546/ijcrbp.2018.511.003 